\title{
Evaluating anthracycline cardiotoxicity associated single nucleotide polymorphisms in a paediatric cohort with early onset cardiomyopathy
}

Timothy N. McOwan ${ }^{1,2+}$, Lauren A. Craig ${ }^{1+}$, Anne Tripdayonis ${ }^{1}$, Kathy Karavendzas ${ }^{1}$, Michael M. Cheung ${ }^{1,2}$, Enzo R. Porrello ${ }^{1,3}$, Rachel Conyers ${ }^{1,2^{*}}$ and David A. Elliott ${ }^{1,2,4^{*}}$ (D)

\begin{abstract}
Background: Anthracyclines are a mainstay of chemotherapy. However, a relatively frequent adverse outcome of anthracycline treatment is cardiomyopathy. Multiple genetic studies have begun to dissect the complex genetics underlying cardiac sensitivity to the anthracycline drug class. A number of single nucleotide polymorphisms (SNPs) have been identified to be in linkage disequilibrium with anthracycline induced cardiotoxicity in paediatric populations.

Methods: Here we screened for the presence of SNPs resulting in a missense coding change in a cohort of children with early onset chemotherapy related cardiomyopathy. The SNP identity was evaluated by Sanger sequencing of PCR amplicons from genomic DNA of patients with anthracycline related cardiac dysfunction.

Results: All of the published SNPs were observed within our patient group. There was no correlation between the number of missense variants an individual carried with severity of disease. Furthermore, the time to cardiac disease onset post-treatment was not greater in those individuals carrying a high load of SNPs resulting from missense variants.

Conclusions: We conclude that previously identified missense SNPs are present within a paediatric cohort with early onset heart damage induced by anthracyclines. However, these SNPs require further replication cohorts and functional validation before being deployed to assess anthracycline cardiotoxicity risk in the clinic.
\end{abstract}

Keywords: Anthracycline induced cardiomyopathy, Genetic variants, Paediatric cancers

\section{Background}

Anthracyclines exhibit proven efficacy as an anti-neoplastic agent but are associated with significant adverse outcomes, particularly cardiotoxicity $[1,2]$. Importantly, the 5 -year survival rate for paediatric cancer patients now exceeds $80 \%$, meaning these populations are experiencing higher survival

\footnotetext{
*Correspondence: rachel.conyers@mcri.edu.au; david.elliott@mcri.edu.au

${ }^{\dagger}$ Tim McOwan and Lauren Craig contributed equally to this work.

${ }^{1}$ Murdoch Children's Research Institute, The Royal Children's Hospital, Flemington Road, Parkville, Victoria 3052, Australia

Full list of author information is available at the end of the article
}

rates and greater life expectancy than ever before $[3,4]$. Consequently, the proportion of paediatric cancer patients who survive long enough to develop chemotherapy-related heart damage is on the rise $[5,6]$. Hence, late cardiovascular sideeffects, and their clinical implications are becoming an increasingly relevant area of research.

Anthracycline cardiotoxicity (ACT) leads to cardiomyocyte damage, ventricular wall thinning and ultimately manifests as a dilated cardiomyopathy [7]. The onset of ACT can be either acute or chronic, and can be clinically appreciable, or subclinical in its presentation.

(c) The Author(s). 2020 Open Access This article is licensed under a Creative Commons Attribution 4.0 International License, which permits use, sharing, adaptation, distribution and reproduction in any medium or format, as long as you give appropriate credit to the original author(s) and the source, provide a link to the Creative Commons licence, and indicate if changes were made. The images or other third party material in this article are included in the article's Creative Commons licence, unless indicated otherwise in a credit line to the material. If material is not included in the article's Creative Commons licence and your intended use is not permitted by statutory regulation or exceeds the permitted use, you will need to obtain permission directly from the copyright holder. To view a copy of this licence, visit http://creativecommons.org/licenses/by/4.0/ The Creative Commons Public Domain Dedication waiver (http://creativecommons.org/publicdomain/zero/1.0/) applies to the data made available in this article, unless otherwise stated in a credit line to the data. 
Acute ACT occurs within a week of commencing treatment and occurs in less than $1 \%$ of patients [8]. Conversely, chronic ACT is more frequent and develops over an extended period of time in the months to years following treatment [9-11]. Symptomatic ACT is usually defined as congestive cardiac failure, whereas patients with subclinical cardiotoxicity remain asymptomatic. Symptoms and signs of congestive cardiac failure include pulmonary or peripheral oedema, dyspnoea and exercise intolerance [12]. Large cohort studies have found that symptomatic ACT occurs in $1.7-9.8 \%$ of childhood cancer survivors [12, 13]. However, the prevalence of subclinical ACT is less certain, and has been reported to occur in 0 to $57 \%$ of childhood cancer survivors [14]. The vast disparity in prevalence is partly due to inconsistencies in study populations, particularly varied dose and diagnoses, and is complicated by variability in clinician judgment and assessment criteria. The most widely used criteria for assessing left ventricular subclinical cardiotoxicity is echocardiography, particularly fractional shortening (FS) and ejection fraction (EF). These measures are dependent on preload, afterload and contractility and are a measure of systolic function.

ACT has been associated with a cardiac mortality of $6 \%$, as was found in a 5-year survivorship study of patients diagnosed between the ages of 15 and 39 [15]. Consequently, there is a significant incentive to characterize the risk profile of cancer patients undergoing anthracycline therapy, so as to better guide therapeutic decision-making. So far, proposed predictors include but are not limited to; sex, age at diagnosis, and radiation exposure. Consensus is lacking as to their contribution, if any, to the development of ACT. However, it is generally accepted that cumulative anthracycline dose is the single biggest independent risk factor for ACT $[7,12,14,16-19]$. As such, the Children's Oncology Group guidelines for paediatric treatment recommend limiting doses to $450 \mathrm{mg} / \mathrm{m}^{2}$ [20]. Further evaluation of patient risk factors has failed to provide a clear consensus regarding clinical characteristics predicting ACT risk. Without knowledge of individual risk, the burden rests on patients, with life-long cardiac monitoring being required.

Nevertheless, personalized follow-up guidelines for cancer survivors are becoming ever more tangible as we enter a forthcoming era of pharmacogenetic-guided treatment. Moving forward, it is hoped we will identify genetic variants that ascribe higher risk for developing $\mathrm{ACT}$, and thus facilitate more effective, individualized risk stratification for paediatric cancer patients. To this end, genetic analysis of large cohorts of cancer patients treated with anthracyclines have verified the existence of many single nucleotide polymorphisms (SNPs) that are associated with the development of ACT [21-31].
Our group recently conducted a retrospective analysis of 481 childhood cancer survivors treated at two tertiary paediatric hospitals. Of the eligible 286 patients, 20 (7.0\%) were classified as having severe ACT with FS < $24 \%$. We sought to analyse the frequency of SNPs that have been previously associated with cardiotoxicity in this subset of patients. DNA from this cohort was sequenced, and analyzed for the presence of these SNPs. Their frequencies were then contrasted with that of the general population, with the view to further characterize the risk of ACT in this subset of patients with severe cardiotoxicity.

\section{Methods}

\section{Patient cohort}

This retrospective cohort has been previously reported by our group [32]. The study identified 481 patients from the Haematology-Oncology registry at the Royal Children's Hospital and Monash Medical Centre, Melbourne, Australia. Patients were eligible to enter the study if they were diagnosed with paediatric cancer between January 2008 and December 2015. Eligibility criteria included a paediatric cancer diagnosis, exposure to anthracycline chemotherapy and at least one echocardiogram performed to assess cardiac function postchemotherapy. Exclusion criteria included a diagnosis of congenital heart disease. Due to the potential for confounding by acute transient cardiotoxicity, [33] only echocardiograms recorded greater than 17 days after commencing anthracycline therapy were included. Eligible participants were screened for ACT as measured by echocardiogram, specifically fractional shortening and left ventricular ejection fraction (LVEF) using the biplane Simpson's method. Echocardiogram findings were rated as normal ( $\mathrm{FS}>28 \%$ and without a $10 \%$ decline in LVEF from baseline), intermediate (FS $24-28 \%$ or a drop in baseline LVEF of $>10 \%$ ) or severe (FS $\leq 24 \%$ ). Blood samples were taken and stored for DNA extraction. The total cumulative dose for each patient was determined using doxorubicin equivalents [34]. Ethics approval was given by the institutional review board (HREC25102D).

\section{DNA sequencing}

DNA extraction was performed using QIAgility (Qiagen $^{\text {тा }}$, Cat \#9001532) and QIAmp 96 DNA QIAcube HT kit (Qiagen ${ }^{\mathrm{nw}}$, Cat \#51331). Primers for PCR amplification and sequencing were designed using Primer-BLAST ${ }^{\mathrm{m}}$ from the National Centre for Biotechnology Information (NCBI). Primers are listed in Supplementary Table 1 (Sigma, Castle Hill, Australia) and amplified using GoTaq $^{\circ}$ (Promega $^{\mathrm{Tu}}$, Cat \#M30001). DNA products were treated with ExoProStar ${ }^{\mathrm{mm}}$ (GE Healthcare Life Sciences, GEHEUS77705). Sequencing was performed by the Australian Genome Research Facility (AGRF) by Sanger 
sequencing using the amplification primers. Primers and PCR conditions are presented in supplementary methods. Homozygous sequences were confirmed by sub-cloning PCR amplicons into pGEM ${ }^{\circ}$ T Easy vector system (Promega, A137A) and sequenced using M13 forward.

\section{Results}

Twenty (20) patients were identified with severe ACT with a fractional shortening $<24 \%$ [32]. Of these fifteen consented to genetic analysis to assess the number of anthracycline cardiotoxicity associated SNPs (Table 1). The mean age of these severe ACT patients was 6.2 years at the time of survey with a range of 0 to 17 years (Supplementary Table 2). The mean cumulative anthracycline dose was $211.2 \mathrm{mg} / \mathrm{m}^{2}\left(51-435 \mathrm{mg} / \mathrm{m}^{2}\right)$. Females are represented disproportionately in this cohort (10 females vs 5 males) (Supplementary Table 2). The distribution of clinical diagnoses is representative of reported frequencies in the paediatric population. Acute lymphoblastic leukaemia (6) and acute myeloid leukaemia (3) were the most common cancers, with a further two each of Wilms Tumour and Ewings Sarcoma and a single individual with Non-Hodgkin's Lymphoma. Patients received the anthracyclines daunorubicin, doxorubicin, mitoxantrone and idarubicin (Table 1). While the mean time in days from baseline to the first abnormal echocardiogram was 394 days, the range was 17 to 1805 days with a median of 145 days (Table 1 ). Three of the patients had a significantly delayed time to detection of cardiac systolic dysfunction of greater than 1000 days. Patients 4, 9 and 12 had delay of 1343, 1805 and 1151 days respectively to first abnormal echocardiogram. Excluding this 'late-onset' subset, the average days from baseline to the first abnormal echocardiogram was 134 days.

Previously identified SNPs associated with anthracycline-induced cardiotoxicity are summarised in Supplementary Table 3. These variants are distributed between missense, synonymous, intronic, and upstream and downstream of associated genes. The frequency of each variant in the 1000 Genomes (1KGP) and Genomes Aggregate (gnomAD) databases is presented. These frequencies range from 4 to $82 \%$. Several of these genes have been previously identified in association with other diseases $[35,36]$. Of the variants previously identified, missense variants are reported in eight genes. These eight genes were the focus of our study, as they were considered most likely to directly affect the mechanism of cardiotoxicity. The frequency of these genetic variants in our cohort was compared to the global frequencies reported in the 1000 Genomes Project.

Patients with severe ACT were then tested for the presence of eight previously-reported missense variants, Table 2. All of these variants were found in at least one patient, however, none were found in all patients. Variants in ETFB, $A B C C 2$, GPR35 and RARG were reported as heterozygous variants, while $C Y B A, N O S 3$ and $C B R 3$ were reported as both homozygous and heterozygous variants. The highest burden of variants in a single patient was 7 , in a combination of both homozygous and heterozygous variants. One patient reported none of the eight-missense variants screened. The variant burden in our cohort of patients with severe ACT ranged from 0 to 7 . While this is an observational study evaluating the

Table 1 Individual patient anthracycline dosage, time to first diagnosis and fractional shortening percentage

\begin{tabular}{|c|c|c|c|c|}
\hline Individual & Drug $^{a}$ & $\begin{array}{l}\text { Cumulative Dose } \\
\left(\mathrm{mg} / \mathrm{m}^{2}\right)\end{array}$ & FS $\%^{\mathbf{b}}$ & Time (days) to initial abnormal echo. \\
\hline 1 & Daun & 435 & 14 & 276 \\
\hline 2 & Daun, Mitox & 410 & 23.3 & 145 \\
\hline 3 & Dox & 356 & 22.9 & 267 \\
\hline 4 & Daun, Dox & 325 & 6 & 1343 \\
\hline 5 & Dox & 260 & 23.9 & 81 \\
\hline 6 & Dox & 255 & 23.1 & 64 \\
\hline 7 & Daun & 204 & 19.7 & 71 \\
\hline 8 & Daun & 200 & 21.5 & 26 \\
\hline 9 & Daun, Dox & 178 & 23 & 1805 \\
\hline 10 & Daun, Dox & 175 & 23.5 & 253 \\
\hline 11 & Daun, Ida & 161 & 23.9 & 17 \\
\hline 12 & Daun, Dox & 147 & 20.5 & 1151 \\
\hline 13 & Daun, Dox & 136 & 19.9 & 88 \\
\hline 14 & Dox & 72 & 23.3 & 214 \\
\hline 15 & Dox & 51 & 23.9 & 106 \\
\hline
\end{tabular}

${ }^{\mathbf{a}}$ Daun daunorubicin; Dox doxorubin; Mitox mitroxantrone; Ida Idarubicin. ${ }^{\mathbf{b}}$ most abnormal record of fractional shortening. ${ }^{\mathbf{c}}$ echo echocardiography 
Table 2 Presence and zygosity status of anthracycline cardiotoxicity associated SNPs in patients with cardiotoxicity

\begin{tabular}{|c|c|c|c|c|c|c|c|c|}
\hline & NOS3 & $E T F B$ & CBR3 & $A B C C 21$ & $A B C C 22$ & RARG & GRP35 & CYBA \\
\hline & rs1799983 & rs79338777 & rs1056892 & rs 17222723 & rs8187710 & rs2229774 & rs12468485 & rs4673 \\
\hline \multicolumn{9}{|c|}{ Patient } \\
\hline 1 & $\mathrm{Het}^{\mathrm{b}}$ & & & & & & & \\
\hline 2 & & Het & Hom & Het & Het & & & \\
\hline 3 & $\mathrm{Hom}^{\mathrm{a}}$ & & & Het & Het & & & \\
\hline 4 & Hom & Het & Het & Het & Het & Het & & Het \\
\hline 5 & Het & & Het & Het & Het & & & Het \\
\hline 6 & Het & & Hom & & & Het & & Hom \\
\hline \multicolumn{9}{|l|}{7} \\
\hline 8 & & & & & & & Het & Hom \\
\hline 9 & Hom & & Hom & & & & & Het \\
\hline 10 & Hom & & & Het & Het & Het & & Het \\
\hline 11 & Hom & & Het & & & & & Het \\
\hline 12 & Hom & & Het & & & & & Het \\
\hline 13 & Hom & & Hom & & & & Het & Hom \\
\hline 14 & Hom & & Het & Het & Het & & & Het \\
\hline 15 & Het & & & & & & & \\
\hline
\end{tabular}

reported SNPs in a small cohort of children treated with anthracycline the frequency of the variants observed is broadly in line with the known frequency of these SNPs in the general population (Table 3). Total cumulative dose of anthracycline given did not correlate with the number of variants reported. Similarly, the number of variants each patient carries did not relate to the time from baseline to first abnormal echocardiogram or the most abnormal FS.

\section{Discussion}

In this study we have examined genetic variants previously associated with ACT in a cohort of severely affected paediatric patients. Severe ACT was defined as a fractional shortening $<24 \%$ as measured by echocardiogram, which was observed in $7 \%$ of the retrospective cohort [32]. These patients varied in clinical diagnosis, age, total cumulative anthracycline dose and time to abnormal echocardiogram, reflecting the patient population treated at two major Australian paediatric hospitals. Our data suggest that, at present these variants cannot accurately predict cardiac sensitivity to anthracycline.

We focussed on the previously reported nonsynonomous variants associated with ACT, reasoning that these protein changes were most likely to directly alter anthracycline pharmacodynamics, thus contributing to cardiotoxicity [37].. A total of 15 genes have been associated with a genetic predisposition to anthracycline cardiomyopathy $[21-27,30,38-40]$. We excluded screening for variants in non-coding sequences or those that encoded a synonymous amino acid change, focussing on variants which modified the amino acid sequence of a given protein. For example, RARG rs2229774 (RARG (1280C $>T^{\text {; }}$ p.S427L) was significantly associated with ACT in a cohort of 280 European Canadian patients (32 ACT cases and 248 controls) and a replication cohort of 96 European Dutch (22 cases and 74 controls) [21]. In an attempt to validate these associations in the setting of early onset severe ACT, our study identified that 14 out of 15 patients had at least one of the missense variants associated with cardiotoxicity to

Table 3 Frequency of missense variants in patients with severe anthracycline-induced cardiotoxicity compared to global population

\begin{tabular}{|c|c|c|c|c|c|c|c|c|}
\hline Gene & NOS3 & ETFB & CBR3 & $A B C C 21$ & $A B C C 22$ & $R A R G$ & GRP35 & $C Y B A$ \\
\hline SNP & rs1799983 & rs79338777 & rs1056892 & rs17222723 & rs8187710 & rs2229774 & rs12468485 & rs4673 \\
\hline Total (of 15) & 12 & 2 & 9 & 6 & 6 & 3 & 2 & 10 \\
\hline Percentage & 80 & 13.33 & 60 & 40 & 40 & 20 & 13.33 & 66.67 \\
\hline Reported Frequency ${ }^{a}$ & 82 & 8 & 43 & 4 & 7 & 9 & 5 & 66 \\
\hline
\end{tabular}

1000 genomes reported global frequency 
date. Nevertheless, incorporating these genetic markers into practice requires replication studies and further functional validation [41].

Importantly, both the onset of cardiotoxicity after anthracycline treatment and the dose at which cardiotoxicity was observed did not correlate with the burden of variants within this cohort. While all variants examined where found within the cohort, with 14 out of 15 patients having at least one variant, no single variant was observed in all patients. In agreement with our current understanding, this suggests the genetic risk of ACT is polygenic in nature and supports further genetic studies with larger cohorts.

\section{Conclusion}

While previously published missense variants are found within our ACT cohort, further functional validation is required to determine the pathogenic mechanism underlying ACT in individuals carrying these variants. The clinical utility of these variants as predictors of anthracycline cardiotoxicity requires detailed studies in much larger cohorts of paediatric cancer survivors.

\section{Supplementary information}

Supplementary information accompanies this paper at https://doi.org/10. 1186/s40959-020-00060-0.

Additional file 1: Table S1. Primers amplifying DNA including the identified SNP for identification of previously identified missense variants associated with anthracycline cardiotoxicity. Table S2. Sex, age at diagnosis and tumour type of study cohort*. Table S3. Published single nucleotide polymorphisms (SNPs) associated with anthracycline-induced cardiotoxicity

\section{Abbreviations \\ SNP: Single nucleotide polymorphism; ACT: Anthracycline induced cardiotoxicity; LVEF: Left ventricular ejection fraction; FS: Fractional shortening}

\section{Acknowledgments}

This work was supported by the Children's Cancer Foundation, My Room, The Royal Children's Hospital Foundation (RC, DAE, ERP). Coded data were supplied by the Children's Cancer Centre Tissue Bank at the Murdoch Children's Research Institute and The Royal Children's Hospital. The Children's Cancer Centre Tissue Bank is made possible through generous support by Cancer In Kids @ RCH (www.cika.org.au), The Royal Children's Hospital Foundation and the Murdoch Children's Research Institute. Supported by the Victorian Government's Operational Infrastructure Support Program and Australian Government National Health and Medical Research Council Independent Research Institute Infrastructure Support Scheme (NHMRC IRIISS). Research in the laboratories of DAE and EP was supported by the NHMRC, the Australian Research Council Strategic Initiative in Stem Cell Science (SR1 10001002) and the Stafford Fox Medical Research Foundation.

\section{Authors' contributions}

TM, LC, AT, KK, collected and analysed data. MMC, ERP obtained funding and analysed data. TM, wrote manuscript. AT, RC collected patient samples. DAE, RC conception, funding, writing and editing. All authors read and approved the final manuscript.

\section{Funding}

Study was supported by Children's Cancer Foundation, My Room, The Royal Children's Hospital Foundation (RC, DAE). The Royal Children's Hospital Children's Cancer Centre Tissue Bank is funded by Cancer In Kids @ RCH (www.cika.org.au) and The Royal Children's Hospital Foundation. Supported by the Victorian Government's Operational Infrastructure Support Program and Australian Government National Health and Medical Research Council Independent Research Institute Infrastructure Support Scheme (NHMRC IRIISS)

\section{Availability of data and materials}

All data and materials are available upon request.

\section{Ethics approval and consent to participate}

Ethics approval was given by the institutional review board (HREC25102D) and consent to participate was obtained in accordance with protocols laid out in HREC25102D.

Consent for publication

All authors consent for publication.

\section{Competing interests}

The authors have no competing interests to declare.

\section{Author details}

'Murdoch Children's Research Institute, The Royal Children's Hospital, Flemington Road, Parkville, Victoria 3052, Australia. ²Department of Pediatrics, The Royal Children's Hospital, University of Melbourne, Parkville, Victoria 3052, Australia. ${ }^{3}$ Department of Physiology, School of Biomedical Sciences, The University of Melbourne, Parkville, Victoria 3010, Australia. ${ }^{4}$ Australian Regenerative Medicine Institute, Monash University, Clayton, Victoria 3800, Australia.

Received: 1 March 2020 Accepted: 29 April 2020

Published online: 21 May 2020

\section{References}

1. Bonadonna G, Monfardini S. Cardiac toxicity of daunorubicin. Lancet (London, England). 1969;1(7599):837.

2. Von Hoff DD, Layard MW, Basa P, Davis HL Jr, Von Hoff AL, Rozencweig M, Muggia FM. Risk factors for doxorubicin-induced congestive heart failure. Ann Intern Med. 1979;91(5):710-7.

3. Robison LL, Hudson MM. Survivors of childhood and adolescent cancer: lifelong risks and responsibilities. Nat Rev Cancer. 2014;14(1):61-70.

4. Howlader N, Noone AM, Krapcho M, Miller D, Brest A, Yu M, Ruhl J, Tatalovich Z, Mariotto A, Lewis DR et al: SEER Cancer Statistics Review, 1975-2016. In. Edited by Institute. NC. Bethesda, MD: NIH; 2019.

5. Armstrong GT, Kawashima T, Leisenring W, Stratton K, Stovall M, Hudson MM, Sklar CA, Robison LL, Oeffinger KC. Aging and risk of severe, disabling, life-threatening, and fatal events in the childhood cancer survivor study. J Clin Oncol. 2014:32(12):1218-27.

6. Hudson MM, Ness KK, Gurney JG, Mulrooney DA, Chemaitilly W, Krull KR, Green DM, Armstrong GT, Nottage KA, Jones KE, et al. Clinical ascertainment of health outcomes among adults treated for childhood cancer. Jama. 2013; 309(22):2371-81

7. Lipshultz SE, Lipsitz SR, Sallan SE, Dalton VM, Mone SM, Gelber RD, Colan SD. Chronic progressive cardiac dysfunction years after doxorubicin therapy for childhood acute lymphoblastic leukemia. J Clin Oncol. 2005;23(12):2629-36.

8. Barry E, Alvarez JA, Scully RE, Miller TL, Lipshultz SE. Anthracycline-induced cardiotoxicity: course, pathophysiology, prevention and management. Expert Opin Pharmacother. 2007:8(8):1039-58

9. Lipshultz SE, Alvarez JA, Scully RE. Anthracycline associated cardiotoxicity in survivors of childhood cancer. Heart. 2008;94(4):525-33.

10. Cardinale D, Colombo A, Bacchiani G, Tedeschi I, Meroni CA, Veglia F, Civelli M, Lamantia G, Colombo N, Curigliano G, et al. Early detection of anthracycline cardiotoxicity and improvement with heart failure therapy. Circulation. 2015:131(22):1981-8.

11. Ali MK, Ewer MS, Gibbs HR, Swafford J, Graff KL. Late doxorubicin-associated cardiotoxicity in children. The possible role of intercurrent viral infection. Cancer. 1994;74(1):182-8. 
12. van Dalen EC, van der Pal HJ, Kok WE, Caron HN, Kremer LC. Clinical heart failure in a cohort of children treated with anthracyclines: a long-term follow-up study. Eur J Cancer (Oxford, England: 1990). 2006;42(18):3191-8.

13. Mulrooney DA, Yeazel MW, Kawashima T, Mertens AC, Mitby P, Stovall M, Donaldson SS, Green DM, Sklar CA, Robison LL, et al. Cardiac outcomes in a cohort of adult survivors of childhood and adolescent cancer: retrospective analysis of the childhood Cancer survivor study cohort. BMJ. 2009;339.

14. Kremer LCM, van der Pal HJH, Offringa M, van Dalen EC, Voûte PA. Frequency and risk factors of subclinical cardiotoxicity after anthracycline therapy in children: a systematic review. Ann Oncol. 2002;13(6):819-29.

15. Henson KE, Reulen RC, Winter DL, Bright CJ, Fidler MM, Frobisher C, Guha J, Wong KF, Kelly J, Edgar AB, et al. Cardiac mortality among 200000 five-year survivors of Cancer diagnosed at 15 to 39 years of age: the teenage and young adult Cancer survivor study. Circulation. 2016;134(20):1519-31.

16. Hudson MM, Rai SN, Nunez C, Merchant TE, Marina NM, Zalamea N, Cox C Phipps S, Pompeu R, Rosenthal D. Noninvasive evaluation of late anthracycline cardiac toxicity in childhood cancer survivors. J Clin Oncol. 2007;25(24):3635-43.

17. Sorensen K, Levitt G, Bull C, Chessells J, Sullivan I. Anthracycline dose in childhood acute lymphoblastic leukemia: issues of early survival versus late cardiotoxicity. J Clin Oncol. 1997;15(1):61-8.

18. Nysom K, Holm K, Lipsitz SR, Mone SM, Colan SD, Orav EJ, Sallan SE, Olsen $J H$, Hertz $H$, Jacobsen JR, et al. Relationship between cumulative anthracycline dose and late cardiotoxicity in childhood acute lymphoblastic leukemia. J Clin Oncol. 1998;16(2):545-50.

19. Sorensen K, Levitt GA, Bull C, Dorup I, Sullivan ID. Late anthracycline cardiotoxicity after childhood cancer: a prospective longitudinal study. Cancer. 2003;97(8):1991-8.

20. Long-term Follow-Up Guidelines for Survivors of Childhood, Adolescent, and Young Adult Cancers. Children's Oncology Group. 2018. http://www. survivorshipguidelines.org/

21. Aminkeng F, Bhavsar AP, Visscher $H$, Rassekh SR, Li Y, Lee JW, Brunham LR, Caron HN, van Dalen EC, Kremer LC, et al. A coding variant in RARG confers susceptibility to anthracycline-induced cardiotoxicity in childhood cancer. Nat Genet. 2015;47(9):1079-84.

22. Semsei AF, Erdelyi DJ, Ungvari I, Csagoly E, Hegyi MZ, Kiszel PS, LautnerCsorba O, Szabolcs J, Masat P, Fekete G, et al. ABCC1 polymorphisms in anthracycline-induced cardiotoxicity in childhood acute lymphoblastic leukaemia. Cell Biol Int. 2012;36(1):79-86.

23. Wang $X$, Sun $C L$, Quinones-Lombrana A, Singh $P$, Landier W, Hageman L, Mather M, Rotter Jl, Taylor KD, Chen YD, et al. CELF4 variant and Anthracycline-related cardiomyopathy: a Children's oncology group genome-wide association study. J Clin Oncol. 2016;34(8):863-70.

24. Ruiz-Pinto S, Pita G, Patino-Garcia A, Alonso J, Perez-Martinez A, Carton AJ, Gutierrez-Larraya F, Alonso MR, Barnes DR, Dennis J, et al. Exome array analysis identifies GPR35 as a novel susceptibility gene for anthracyclineinduced cardiotoxicity in childhood cancer. Pharmacogenet Genomics. 2017;27(12):445-53.

25. Ruiz-Pinto S, Pita G, Martin M, Alonso-Gordoa T, Barnes DR, Alonso MR, Herraez B, Garcia-Miguel P, Alonso J, Perez-Martinez A, et al. Exome array analysis identifies ETFB as a novel susceptibility gene for anthracycline-induced cardiotoxicity in cancer patients. Breast Cancer Res Treat. 2018;167(1):249-56.

26. Blanco JG, Leisenring WM, Gonzalez-Covarrubias VM, Kawashima TI, Davies SM, Relling MV, Robison LL, Sklar CA, Stovall M, Bhatia S. Genetic polymorphisms in the carbonyl reductase 3 gene $C B R 3$ and the $N A D(P) H$ : quinone oxidoreductase 1 gene NQO1 in patients who developed anthracycline-related congestive heart failure after childhood cancer. Cancer. 2008;112(12):2789-95.

27. Wang $X$, Liu W, Sun CL, Armenian SH, Hakonarson H, Hageman L, Ding $Y$, Landier W, Blanco JG, Chen L, et al. Hyaluronan synthase 3 variant and anthracycline-related cardiomyopathy: a report from the children's oncology group. J Clin Oncol. 2014;32(7):647-53.

28. Wojnowski L, Kulle B, Schirmer M, Schluter G, Schmidt A, Rosenberger A, Vonhof S, Bickeboller H, Toliat MR, Suk EK, et al. NAD(P)H oxidase and multidrug resistance protein genetic polymorphisms are associated with doxorubicin-induced cardiotoxicity. Circulation. 2005;112(24):3754-62.

29. Krajinovic M, Elbared J, Drouin S, Bertout L, Rezgui A, Ansari M, Raboisson MJ, Lipshultz SE, Silverman LB, Sallan SE, et al. Polymorphisms of ABCC5 and NOS3 genes influence doxorubicin cardiotoxicity in survivors of childhood acute lymphoblastic leukemia. Pharmacogenomics J. 2016;16(6):530-5.
30. Visscher H, Ross CJ, Rassekh SR, Sandor GS, Caron HN, van Dalen EC, Kremer LC, van der Pal HJ, Rogers PC, Rieder MJ, et al. Validation of variants in SLC28A3 and UGT1A6 as genetic markers predictive of anthracyclineinduced cardiotoxicity in children. Pediatr Blood Cancer. 2013;60(8):1375-81.

31. Hertz DL, Caram MV, Kidwell KM, Thibert JN, Gersch C, Seewald NJ, Smerage J, Rubenfire M, Henry NL, Cooney KA, et al. Evidence for association of SNPs in $A B C B 1$ and CBR3, but not RAC2, NCF4, SLC28A3 or TOP2B, with chronic cardiotoxicity in a cohort of breast cancer patients treated with anthracyclines. Pharmacogenomics. 2016;17(3):231-40.

32. Conyers R, Costello B, La Gerche A, Tripaydonis A, Burns C, Ludlow L, Lange $P$, Ekert $P$, Mechinaud $F$, Cheung $M$, et al. Chemotherapy-related cardiotoxicity: are Australian practitioners missing the point? Intern Med J. 2017:47(10):1166-72.

33. Giantris A, Abdurrahman L, Hinkle A, Asselin B, Lipshultz SE. Anthracyclineinduced cardiotoxicity in children and young adults. Crit Rev Oncol Hematol. 1998;27(1):53-68.

34. Felker GM, Thompson RE, Hare JM, Hruban RH, Clemetson DE, Howard DL, Baughman KL, Kasper EK. Underlying causes and long-term survival in patients with initially unexplained cardiomyopathy. N Engl J Med. 2000; 342(15):1077-84.

35. Chen P, Yang W, Tian Y, Sun S, Chen G, Zhang C, Ma F, Xun Y, Shi L, Yang $C$, et al. Electron transfer Flavoprotein subunit Beta is a candidate endothelial cell autoantigen in Behcet's disease. PLoS One. 2015;10(4): e0124760.

36. Garme Y, Saravani R, Galavi HR. Association of nitric oxide synthase 3 gene polymorphism with the risk of type 2 diabetes. Biomedical reports. 2017; 7(1):85-9.

37. Aminkeng F, Ross CJ, Rassekh SR, Hwang S, Rieder MJ, Bhavsar AP, Smith A, Sanatani S, Gelmon KA, Bernstein D, et al. Recommendations for genetic testing to reduce the incidence of anthracycline-induced cardiotoxicity. Br J Clin Pharmacol. 2016:82(3):683-95.

38. Blanco JG, Sun C-L, Landier W, Chen L, Esparza-Duran D, Leisenring W, Mays A, Friedman DL, Ginsberg JP, Hudson MM, et al. Anthracycline-related cardiomyopathy after childhood cancer: role of polymorphisms in carbonyl reductase genes--a report from the children\&apos;s oncology group. J Clin Oncol. 2012;30:1415-21.

39. Rajic V, Aplenc R, Debeljak M, Prestor W, Karas-Kuzelicki N, Mlinaric-Rascan I, Jazbec J. Influence of the polymorphism in candidate genes on late cardiac damage in patients treated due to acute leukemia in childhood. Leuk Lymphoma. 2009;50(10):1693-8.

40. Visscher H, Ross CJD, Rassekh SR, Barhdadi A, Dubé M-P, Al-Saloos H, Sandor GS, Caron HN, van Dalen EC, Kremer LC, et al. Pharmacogenomic prediction of anthracycline-induced cardiotoxicity in children. J Clin Oncol. 2012;30: $1422-8$.

41. Tripaydonis A, Conyers R, Elliott DA. Pediatric Anthracycline-induced Cardiotoxicity: mechanisms, pharmacogenomics, and pluripotent stem-cell modeling. Clin Pharmacol Ther. 2019;105(3):614-24.

\section{Publisher's Note}

Springer Nature remains neutral with regard to jurisdictional claims in published maps and institutional affiliations.

Ready to submit your research? Choose BMC and benefit from:

- fast, convenient online submission

- thorough peer review by experienced researchers in your field

- rapid publication on acceptance

- support for research data, including large and complex data types

- gold Open Access which fosters wider collaboration and increased citations

- maximum visibility for your research: over $100 \mathrm{M}$ website views per year

At $\mathrm{BMC}$, research is always in progress.

Learn more biomedcentral.com/submission 